\title{
Virgibacillus campisalis sp. nov., from a marine solar saltern
}

Correspondence

Jung-Hoon Yoon

jhyoon69@skku.edu

\author{
Soo-Young Lee, ${ }^{1}$ Chul-Hyung Kang, ${ }^{1}$ Tae-Kwang $\mathrm{Oh}^{1}$ \\ and Jung-Hoon Yoon ${ }^{1,2}$
}

\author{
${ }^{1}$ Korea Research Institute of Bioscience and Biotechnology (KRIBB), PO Box 115, Yuseong, \\ Daejon, Republic of Korea \\ ${ }^{2}$ Department of Food Science and Biotechnology, Sungkyunkwan University, Jangan-gu, Suwon, \\ Republic of Korea
}

\begin{abstract}
A Gram-staining-variable, motile, endospore-forming and rod-shaped bacterial strain, IDS-20 ${ }^{\top}$, was isolated from a marine solar saltern in Korea and subjected to a polyphasic taxonomic investigation. Strain IDS-20 $0^{\top}$ grew optimally at $37{ }^{\circ} \mathrm{C}$, at $\mathrm{pH} 7.5-8.0$ and in the presence of 4$5 \%(\mathrm{w} / \mathrm{v}) \mathrm{NaCl}$. Phylogenetic analysis based on 16S rRNA gene sequences revealed that strain IDS- $20^{\top}$ belongs to the genus Virgibacillus. Strain IDS- $20^{\top}$ exhibited 93.4-96.6\% $16 \mathrm{~S}$ rRNA gene sequence similarity to the type strains of species of the genus Virgibacillus. Strain IDS- $20^{\top}$ had MK-7 as the predominant menaquinone and a cell-wall peptidoglycan based on mesodiaminopimelic acid. The major fatty acids were anteiso- $\mathrm{C}_{15: 0}$ and anteiso- $\mathrm{C}_{17: 0}$ and major polar lipids were diphosphatidylglycerol, phosphatidylglycerol and two unidentified phospholipids. The DNA G +C content was 39.5 mol\%. The phylogenetic distinctiveness and differential phenotypic characteristics of strain IDS $-20^{\top}$ demonstrated that this strain can be distinguished from recognized species of the genus Virgibacillus. On the basis of the data presented, strain IDS- $20^{\top}$ represents a novel species of the genus Virgibacillus, for which the name Virgibacillus campisalis

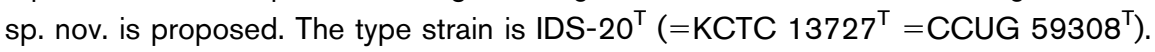

The genus Virgibacillus was created by Heyndrickx et al. (1998) through the reclassification of Bacillus pantothenticus. At the time of writing, the genus comprises at least 21 species with validly published names, including the recently described species Virgibacillus chiguensis (Wang et al., 2008), V. kekensis (Chen et al., 2008), V. salarius (Hua et al., 2008), $V$. sediminis (Chen et al., 2009), V. arcticus (Niederberger et al., 2009), V. salinus (Carrasco et al., 2009), V. byunsanensis (Yoon et al., 2010), V. xinjiangensis (Jeon et al., 2009, 2010), $V$. subterraneus (Wang et al., 2010) and V. soli (Kämpfer et al., 2011). Members of the genus Virgibacillus were characterized chemotaxonomically by having meso-diaminopimelic acid as the diagnostic diamino acid in the peptidoglycan, MK-7 as the predominant menaquinone and anteiso- $\mathrm{C}_{15: 0}$ as the common major fatty acid (Chen et al., 2008, 2009; Hua et al., 2008; Kämpfer et al., 2011). However, a species of the genus Virgibacillus, V. arcticus, having L-lysine as the diagnostic diamino acid has been described (Niederberger et al., 2009). In this study, a bacterial strain, IDS- $20^{\mathrm{T}}$, which was isolated from a marine solar saltern on the west coast of Korea, is described. Comparative 16S rRNA gene sequence analysis

The GenBank/EMBL/DDBJ accession number for the 16S rRNA gene sequence of strain IDS- $20^{\top}$ is GU586225.

Three supplementary figures are available with the online version of this paper. indicated that strain IDS- $20^{\mathrm{T}}$ should be considered to be a member of the genus Virgibacillus. The aim of the present work was to determine the exact taxonomic position of strain IDS $-20^{\mathrm{T}}$ by using a polyphasic characterization that included the determination of phenotypic properties, a detailed phylogenetic investigation based on $16 \mathrm{~S}$ rRNA gene sequences and genetic analysis.

A sediment sample collected from a marine solar saltern of Byunsan, Korea, was suspended in a $0.85 \%(\mathrm{w} / \mathrm{v}) \mathrm{NaCl}$ solution. The suspension was diluted serially, spread on modified S-G medium (Sehgal \& Gibbons, 1960) solidified with $1.5 \%(\mathrm{w} / \mathrm{v})$ agar and incubated at $25{ }^{\circ} \mathrm{C}$. This medium contained the following components $\left(1^{-1}\right.$ distilled water): $100 \mathrm{~g} \mathrm{NaCl}, 20 \mathrm{~g} \mathrm{MgSO}_{4} \cdot 7 \mathrm{H}_{2} \mathrm{O}, 2 \mathrm{~g} \mathrm{KCl}, 3 \mathrm{~g}$ trisodium citrate, 10 g yeast extract and $7.5 \mathrm{~g}$ Casamino acids ( $\mathrm{pH}$ 7.2). The morphological, physiological and biochemical properties of strain IDS $-20^{\mathrm{T}}$ were investigated using routine cultivation at $37{ }^{\circ} \mathrm{C}$ on another modified S-G (MSG) medium which contained $\left(1^{-1}\right.$ distilled water $50 \mathrm{~g} \mathrm{NaCl}, 20 \mathrm{~g}$ $\mathrm{MgSO}_{4} \cdot 7 \mathrm{H}_{2} \mathrm{O}, 2 \mathrm{~g} \mathrm{KCl}, 3 \mathrm{~g}$ trisodium citrate, $10 \mathrm{~g}$ yeast extract and $7.5 \mathrm{~g}$ Casamino acids ( $\mathrm{pH} 7.2)$. Cell morphology was determined by light microscopy (Nikon E600) and transmission electron microscopy (Philips CM-20). The presence of flagella was investigated by using a transmission electron microscope with cells from exponentially growing 
cultures. For this purpose, the cells were negatively stained with $1 \%(w / v)$ phosphotungstic acid and the grids were examined after being air-dried. The Gram reaction was performed by using the bioMérieux Gram stain kit according to the manufacturer's instructions. Growth under anaerobic conditions was determined after incubation in a Forma anaerobic chamber on MSG agar and on MSG agar supplemented with $0.1 \%(\mathrm{w} / \mathrm{v})$ potassium nitrate, both of which had been prepared anaerobically under nitrogen atmosphere. Growth at various temperatures $(4,10,15,20$, $25,30,37,40$ and $45^{\circ} \mathrm{C}$ ) was measured on MSG agar. The $\mathrm{pH}$ range for growth and optimal $\mathrm{pH}$ were determined in MSG broth that was adjusted to $\mathrm{pH} 4.5-10.5$ (at intervals of $0.5 \mathrm{pH}$ units) by using sodium acetate/acetic acid and $\mathrm{Na}_{2} \mathrm{CO}_{3}$ buffers. Growth in the absence of $\mathrm{NaCl}$ and growth at various $\mathrm{NaCl}$ concentrations $(0.5 \%$ and $1.0-30.0 \%$, w/v, in increments of $1.0 \%$ ) was investigated by using liquid media prepared according to the formula of the MSG medium except that $\mathrm{NaCl}$ was excluded. Catalase and oxidase activities were determined as described by Cowan \& Steel (1965). Hydrolysis of casein, hypoxanthine, starch and xanthine was tested on MSG agar by using the substrate concentrations described by Cowan \& Steel (1965). Nitrate reduction and hydrolysis of aesculin, gelatin, urea and Tweens 20, 40, 60 and 80 were tested as described by Lányí (1987) by using artificial seawater (Bruns et al., 2001) for preparation of media. The artificial seawater contained $\left(1^{-1}\right.$ distilled water) $23.6 \mathrm{~g} \mathrm{NaCl}, 0.64 \mathrm{~g} \mathrm{KCl}, 4.53 \mathrm{~g}$ $\mathrm{MgCl}_{2} \cdot 6 \mathrm{H}_{2} \mathrm{O}$, $5.94 \mathrm{~g} \mathrm{MgSO}_{4} \cdot 7 \mathrm{H}_{2} \mathrm{O}$ and $1.3 \mathrm{~g} \mathrm{CaCl}_{2}$. $2 \mathrm{H}_{2} \mathrm{O}$ (Bruns et al., 2001). Acid production from various carbohydrates was investigated according to the method of Leifson (1963). Utilization of various substrates was tested

Table 1. Differential phenotypic characteristics of Virgibacillus campisalis IDS- $20^{\top}$ and seven phylogenetically related species of the genus Virgibacillus

Taxa: 1, V. campisalis sp. nov. IDS-20 ${ }^{\mathrm{T}}$; 2. V. arcticus (data from Niederberger et al., 2009); 3. V. byunsanensis (Yoon et al., 2010); 4. V. carmonensis (Heyrman et al., 2003); 5, V. halodenitrificans (Yoon et al., 2004); 6, V. necropolis (Heyrman et al., 2003); 7, V. salinus (Carrasco et al., 2009); 8, V. subterraneus (Wang et al., 2010). +, Positive reaction; -, negative reaction; w, weakly positive reaction; v, variable reaction; ND, not determined. Data in parentheses are for the type strain. All taxa are positive for catalase and nitrate reduction.

\begin{tabular}{|c|c|c|c|c|c|c|c|c|}
\hline Characteristic & 1 & 2 & 3 & 4 & 5 & 6 & 7 & 8 \\
\hline Spore shape ${ }^{*}$ & $\mathrm{~S}$ & E & $\mathrm{S}$ or $\mathrm{O}$ & $\mathrm{S}$ or $\mathrm{E}$ & E & E & $\mathrm{E}$ or $\mathrm{S}$ & E or $S$ \\
\hline Spore position $\dagger$ & $\mathrm{T}$ & $\mathrm{C}$ or ST & $\mathrm{T}$ & ST & $\mathrm{T}$ or $\mathrm{ST}$ & $\mathrm{C}, \mathrm{T}$ or $\mathrm{ST}$ & $\mathrm{T}$ or $\mathrm{ST}$ & $\mathrm{T}$ \\
\hline Anaerobic growth & + & + & - & - & + & - & - & - \\
\hline Gram-staining & $\mathrm{V}$ & + & $\mathrm{v}$ & + & $\mathrm{V}$ & + & + & + \\
\hline Pigmentation & - & Light pink & - & Pink & - & - & Cream & Cream \\
\hline Growth without $\mathrm{NaCl}$ & - & + & + & - & - & $\mathrm{w}$ & - & + \\
\hline \multicolumn{9}{|l|}{ Hydrolysis of: } \\
\hline Aesculin & - & $\mathrm{ND}$ & - & $\mathrm{W}$ & $\mathrm{v}(-)$ & - & + & + \\
\hline Casein & - & + & - & + & + & + & - & - \\
\hline Gelatin & - & + & - & - & + & $\mathrm{w}$ & - & - \\
\hline \multicolumn{9}{|l|}{ Acid production from: } \\
\hline D-Glucose & - & $\mathrm{w}$ & - & - & + & $\mathrm{w}$ & + & + \\
\hline D-Fructose & - & $\mathrm{w}$ & $\mathrm{w}$ & - & + & $\mathrm{w}$ & + & + \\
\hline D-Mannitol & - & + & - & - & $\mathrm{v}(+)$ & - & - & - \\
\hline D-Mannose & - & $\mathrm{w}$ & - & - & + & $\mathrm{w}$ & $\mathrm{ND}$ & + \\
\hline Melibiose & - & + & - & - & - & - & $\mathrm{ND}$ & + \\
\hline Trehalose & - & + & - & - & + & $\mathrm{w}$ & + & - \\
\hline \multicolumn{9}{|l|}{ Utilization of: } \\
\hline D-Glucose & + & + & - & - & + & + & - & + \\
\hline D-Fructose & - & ND & - & - & $\mathrm{v}(+)$ & - & - & + \\
\hline Sucrose & - & + & - & + & + & + & + & + \\
\hline D-Xylose & - & ND & - & - & - & - & + & + \\
\hline Major polar lipids $\ddagger$ & $\begin{array}{l}\text { DPG, } \\
\text { PG, PLs }\end{array}$ & $\begin{array}{l}\text { DPG, } \\
\text { PG, PLs }\end{array}$ & $\begin{array}{l}\text { DPG, } \\
\text { PG, PLs }\end{array}$ & $\begin{array}{l}\text { DPG, } \\
\text { PG, PLs }\end{array}$ & $\begin{array}{c}\text { PG, } \\
\text { DPG, PLs }\end{array}$ & $\begin{array}{l}\text { DPG, } \\
\text { PG, PLs }\end{array}$ & $\begin{array}{l}\text { DPG, PG, } \\
\text { GL, PLs }\end{array}$ & $\begin{array}{c}\text { DPG, PG, } \\
\text { GL }\end{array}$ \\
\hline Cell-wall type & $m$-DAP & L-Lys-direct & $m$-DAP & ND & $m$-DAP & ND & $m$-DAP & $m$-DAP \\
\hline $\begin{array}{l}\text { DNA G + C content } \\
(\mathrm{mol} \%)\end{array}$ & 39.5 & 38.2 & 37.6 & 38.9 & $38-39$ & 37.3 & 38.8 & 37.1 \\
\hline
\end{tabular}

${ }^{\star}$ S, Spherical; O, oval; E, ellipsoidal.

$\dagger \mathrm{T}$, Terminal; ST, subterminal; C, central.

¥PG, Phosphatidylglycerol; DPG, diphosphatidylglycerol; GL, glycolipid; PLs, unidentified phospholipids.

$\S m$, meso. 
according to the method of Baumann \& Baumann (1981) using supplementation with $3 \%(\mathrm{w} / \mathrm{v}) \mathrm{NaCl}, 0.01 \%(\mathrm{w} / \mathrm{v})$ yeast extract, $1 \%(\mathrm{v} / \mathrm{v})$ vitamin solution (Staley, 1968) and $2 \%(\mathrm{v} / \mathrm{v})$ Hutner's mineral salts solution (Cohen-Bazire et al., 1957). Susceptibility to antibiotics was investigated on MSG agar plates by using antibiotic discs with the following concentrations: ampicillin, $10 \mu \mathrm{g}$; carbenicillin, $100 \mu \mathrm{g}$; cephalothin, $30 \mu \mathrm{g}$; chloramphenicol, $100 \mu \mathrm{g}$; gentamicin, $30 \mu \mathrm{g}$; kanamycin, $30 \mu \mathrm{g}$; lincomycin, $15 \mu \mathrm{g} ;$ neomycin, $30 \mu \mathrm{g}$; novobiocin, $5 \mu \mathrm{g}$; oleandomycin, $15 \mu \mathrm{g}$; penicillin $\mathrm{G}$, $20 \mathrm{U}$; polymyxin $\mathrm{B}, 100 \mathrm{U}$; streptomycin, $50 \mu \mathrm{g}$; and tetracycline, $30 \mu \mathrm{g}$. Enzyme activities and other physiological properties were determined by using API ZYM and API 20E systems (bioMérieux). Morphological, cultural, physiological and biochemical characteristics of strain IDS- $20^{\mathrm{T}}$ are shown in Supplementary Fig. S1 (available in IJSEM Online) and given in the species description (see below) and in Table 1.

Cell biomass for DNA extraction and for the analyses of cell wall, isoprenoid quinones and polar lipids was obtained from cultures grown for 3 days in MSG broth at $37{ }^{\circ} \mathrm{C}$. Chromosomal DNA was isolated and purified according to the method described by Yoon et al. (1996), with the exception that RNase T1 was used in combination with
RNase A to minimize the contamination by RNA. The $16 \mathrm{~S}$ rRNA gene was amplified by PCR as described by Yoon et al. (1998) using two universal primers, 9F (5'-GAGTTTGATCCTGGCTCAG-3') and 1542R (5'-AGAAAGGAGGTGATCCAGCC-3'), and purified using a QIAquick PCR purification kit (Qiagen). Sequencing of the amplified 16S rRNA gene and phylogenetic analysis were performed according to the method of Yoon et al. (2003). The near-complete 16S rRNA gene sequence of strain IDS- $20^{\mathrm{T}}$ determined in this study comprised $1523 \mathrm{nt}$. In the phylogenetic trees reconstructed using the neighbour-joining, maximum-likelihood and maximum-parsimony algorithms, strain IDS- $20^{\mathrm{T}}$ fell within the clade comprising species of the genus Virgibacillus (Fig. 1; Supplementary Figs S2 and S3). Strain IDS-20 $20^{\mathrm{T}}$ exhibited the highest 16S rRNA gene sequence similarity $(96.6 \%)$ to Virgibacillus byunsanensis ISL-24 ${ }^{\mathrm{T}}$ and $93.4-$ $96.4 \% 16 \mathrm{~S}$ rRNA gene similarity to the type strains of the other species of the genus Virgibacillus. The DNA G $+\mathrm{C}$ content was determined by the method of Tamaoka \& Komagata (1984) with the modification that DNA was hydrolysed and the resultant nucleotides were analysed by reversed-phase HPLC. The DNA G $+\mathrm{C}$ content of strain IDS- $20^{\mathrm{T}}$ was $39.5 \mathrm{~mol} \%$.

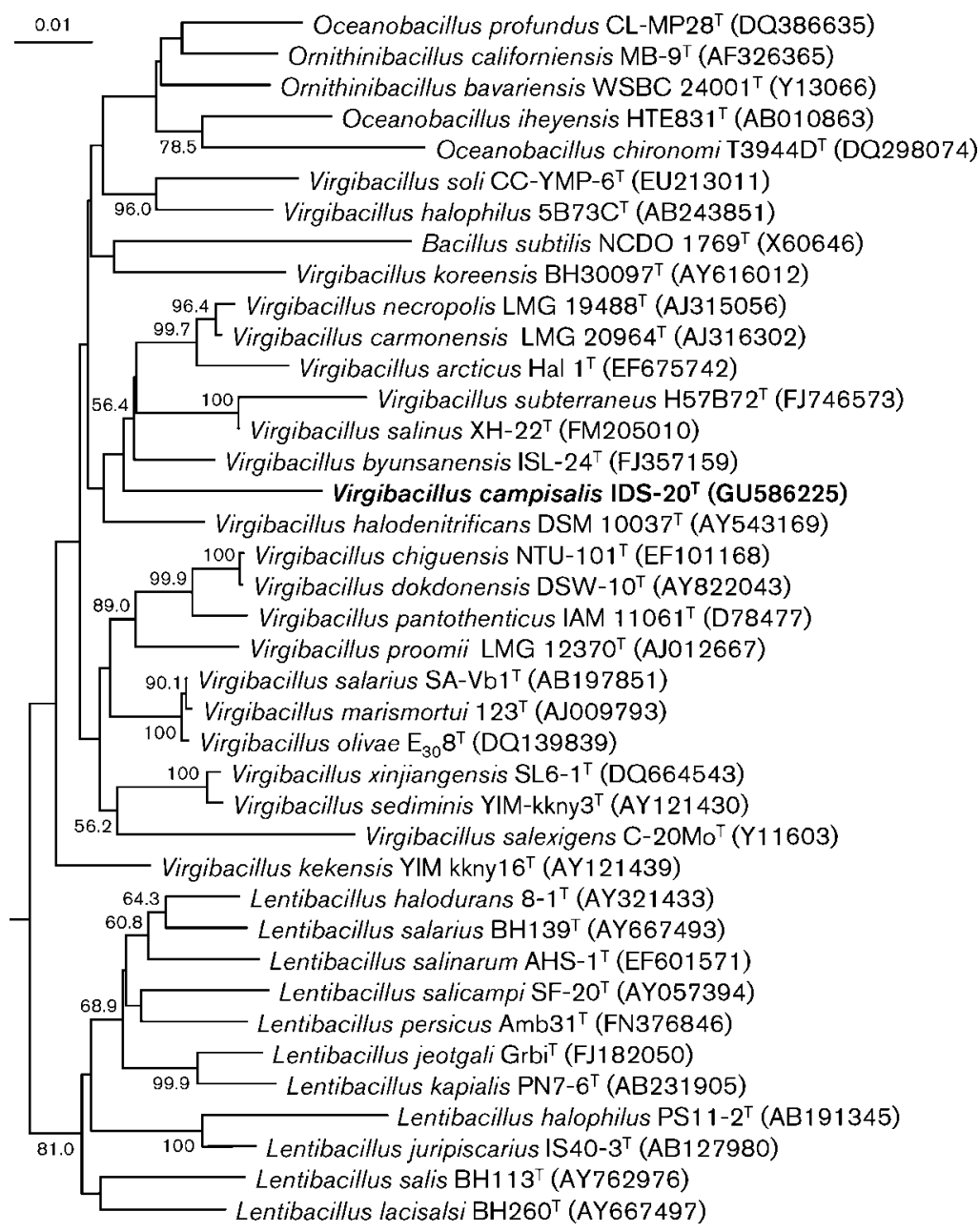

Fig. 1. Neighbour-joining phylogenetic tree (using Jukes-Cantor distance model) based on 16S rRNA gene sequences showing the positions of strain IDS- $20^{\top}$, species of the genus Virgibacillus and some other related taxa. Bootstrap values (expressed as percentages of 1000 replications) of $>50 \%$ are shown at branching points. Alicyclobacillus acidocaldarius DSM $446^{\top}$ was used as an outgroup (not shown). Bar, 0.01 substitutions per nucleotide position. 
The isomer type of the diamino acid in the cell wall peptidoglycan was analysed by using TLC according to the method described by Komagata \& Suzuki (1987). Strain IDS- $20^{\mathrm{T}}$ contained meso-diaminopimelic acid as diagnostic diamino acid in the cell-wall peptidoglycan. Isoprenoid quinones were extracted according to the method of Komagata \& Suzuki (1987) and analysed using reversedphase HPLC and a YMC ODS-A $(250 \times 4.6 \mathrm{~mm})$ column. The predominant isoprenoid quinone detected in strain IDS- $20^{\mathrm{T}}$ was menaquinone-7 (MK-7) at a peak area ratio of approximately $91 \%$. Polar lipids were extracted according to the procedures described by Minnikin et al. (1984) and identified by two-dimensional TLC followed by spraying with appropriate detection reagents (Minnikin et al., 1984; Komagata \& Suzuki, 1987). Major polar lipids detected in strain IDS $-20^{\mathrm{T}}$ were diphosphatidylglycerol, phosphatidylglycerol and two unidentified phospholipids. For cellular fatty acid analysis, cell mass of strain IDS- $20^{\mathrm{T}}$ was harvested from marine agar 2216 (Difco) plates after cultivation for 3 days at $30{ }^{\circ} \mathrm{C}$. The fatty acids were extracted and fatty acid methyl esters were prepared according to the standard protocol of the MIDI/Hewlett Packard Microbial Identification System (Sasser, 1990). The cellular fatty acid profile of strain IDS- $20^{\mathrm{T}}$ is shown in Table 2, together with those of Virgibacillus pantothenticus, the type species of the genus, and some phylogenetically related species of the genus Virgibacillus, which were obtained by using the same conditions. The major fatty acids $(>10 \%$ of total fatty acids) found in strain IDS- $20^{T}$ were anteiso- $\mathrm{C}_{15: 0}$ and anteiso- $\mathrm{C}_{17: 0}$. These chemotaxonomic properties, which are similar to those of species of the genus Virgibacillus, are sufficient to support the result of phylogenetic analysis, i.e. that strain IDS- $20^{\mathrm{T}}$ belongs to the genus Virgibacillus.

Strain IDS $-20^{\mathrm{T}}$ was distinguishable from some phylogenetically related species of the genus Virgibacillus by differences in several phenotypic characteristics as listed in Table 1. Therefore, phylogenetic distinctiveness and differential phenotypic properties of strain IDS $-20^{\mathrm{T}}$ are sufficient to demonstrate that this strain is separate from the recognized species of the genus Virgibacillus. On the basis of the phenotypic and phylogenetic data, strain IDS$20^{\mathrm{T}}$ is considered to represent a novel species of the genus Virgibacillus, for which the name Virgibacillus campisalis sp. nov. is proposed.

\section{Description of Virgibacillus campisalis sp. nov.}

Virgibacillus campisalis (cam.pi.sa'lis. L. n. campus field; L. gen. n. salis of salt; N.L. gen. n. campisalis of the field of salt).

Cells are Gram-staining-variable, facultatively anaerobic and rod-shaped, $0.5-1.0 \mu \mathrm{m}$ in diameter and 1.0-4.0 $\mu \mathrm{m}$ in length. Terminal spherical endospores are observed in swollen sporangia. Motile by means of a single polar flagellum. Colonies on MSG agar are circular, smooth, slightly convex, greyish-yellow and $0.5-1.5 \mathrm{~mm}$ in diameter after incubation for 5 days at $37^{\circ} \mathrm{C}$. Optimal growth temperature is $37^{\circ} \mathrm{C}$; growth occurs at 15 and $40{ }^{\circ} \mathrm{C}$, but
Table 2. Cellular fatty acid compositions (\%) of strain IDS$20^{\top}$ and the type strains of several species of the genus Virgibacillus

Strains: 1 , V. campisalis sp. nov. IDS-20 ${ }^{\mathrm{T}} ; 2$, V. pantothenticus KCTC $3539^{\mathrm{T}} ; 3$, V. byunsanensis ISL-24 ${ }^{\mathrm{T}} ; 4$, V. carmonensis DSM $14868^{\mathrm{T}}$; 5 , V. necropolis DSM $14866^{\mathrm{T}}$. Data for reference strains from Yoon et al. (2010). Fatty acids that represented $<0.5 \%$ in all strains were omitted. tr, Trace $(<0.5 \%)$. -, Not detected.

\begin{tabular}{|lccccc|}
\hline Fatty acid & $\mathbf{1}$ & $\mathbf{2}$ & $\mathbf{3}$ & $\mathbf{4}$ & $\mathbf{5}$ \\
\hline Straight-chain & & & & & \\
$\quad \mathrm{C}_{14: 0}$ & 1.2 & $\operatorname{tr}$ & $\operatorname{tr}$ & $\operatorname{tr}$ & $\operatorname{tr}$ \\
$\mathrm{C}_{15: 0}$ & - & $\operatorname{tr}$ & $\operatorname{tr}$ & 0.9 & $\operatorname{tr}$ \\
$\mathrm{C}_{16: 0}$ & 4.9 & 0.9 & 0.9 & 1.3 & 1.7 \\
Unsaturated & & & & & \\
$\quad \mathrm{C}_{16: 1} \omega 7 c$ alcohol & - & - & $\operatorname{tr}$ & 6.1 & 1.0 \\
Branched & & & & & \\
anteiso-C $13: 0$ & - & $\operatorname{tr}$ & 0.7 & $\operatorname{tr}$ & $\operatorname{tr}$ \\
iso-C $\mathrm{C}_{14: 0}$ & 1.9 & 1.1 & 7.6 & 8.9 & 3.3 \\
iso-C $15: 0$ & 2.1 & 4.8 & 1.2 & 2.6 & 2.2 \\
anteiso-C & 59.0 & 50.4 & 71.7 & 58.7 & 73.0 \\
iso- $\mathrm{C}_{16: 0}$ & 4.8 & 5.5 & 5.2 & 11.7 & 4.9 \\
iso- $\mathrm{C}_{17: 0}$ & - & 2.1 & - & $\operatorname{tr}$ & $\operatorname{tr}$ \\
anteiso-C $17: 0$ & 26.1 & 34.5 & 10.3 & 6.8 & 11.0 \\
Summed feature $4^{*}$ & - & - & 1.1 & 1.6 & 0.9 \\
& & & & & \\
\hline
\end{tabular}

${ }^{\star}$ Summed features represent groups of two or three fatty acids which could not be separated by GLC with the MIDI system. Summed feature 4 contained iso- $\mathrm{C}_{17: 1}$ and/or anteiso- $\mathrm{C}_{17: 1}$.

not at 10 or $45{ }^{\circ} \mathrm{C}$. Optimal $\mathrm{pH}$ for growth is between 7.5 and 8.0; growth occurs at $\mathrm{pH}$ 6.0-9.0. Growth occurs optimally in the presence of $4-5 \%(\mathrm{w} / \mathrm{v}) \mathrm{NaCl}$; growth occurs in the presence of $0.5-20 \%(\mathrm{w} / \mathrm{v}) \mathrm{NaCl}$. Anaerobic growth occurs on MSG and on MSG supplemented with nitrate. Oxidase- and catalase-positive. Arginine dihydrolase, lysine decarboxylase and ornithine decarboxylase activities are absent. Tweens 20, 40, 60 and 80 are hydrolysed, but aesculin, casein, gelatin, hypoxanthine, L-tyrosine, urea and xanthine are not. D-Glucose, acetate, citrate, L-malate, pyruvate and succinate are utilized as sole carbon and energy sources, but L-arabinose, cellobiose, D-fructose, Dgalactose, maltose, D-mannose, sucrose, trehalose, D-xylose, salicin, benzoate, formate and L-glutamate are not. Acid is not produced from L-arabinose, cellobiose, D-galactose, D-glucose, D-fructose, myo-inositol, lactose, maltose, Dmannose, D-mannitol, melezitose, melibiose, raffinose, L-rhamnose, D-ribose, D-sorbitol, sucrose, trehalose or Dxylose. Susceptible to ampicillin, carbenicillin, cephalothin, chloramphenicol, lincomycin, novobiocin, oleandomycin, penicillin $G$ and tetracycline. Tolerant to gentamicin, kanamycin, neomycin, polymyxin B and streptomycin. In assays with the API ZYM system, esterase (C4) and esterase lipase (C8) are present, but alkaline phosphatase, lipase (C14), leucine arylamidase, valine arylamidase, cystine arylamidase, trypsin, $\alpha$-chymotrypsin, acid phosphatase, naphtholAS-BI-phosphohydrolase, $\alpha$-galactosidase, $\beta$-galactosidase, 
$\beta$-glucuronidase, $\alpha$-glucosidase, $\quad N$-acetyl- $\beta$-glucosamine, $\alpha$-mannosidase and $\alpha$-fucosidase are absent. The cell-wall peptidoglycan contains meso-diaminopimelic acid. The major cellular fatty acids ( $>10 \%$ total fatty acids) are anteiso- $\mathrm{C}_{15: 0}$ and anteiso- $\mathrm{C}_{17: 0}$. The predominant menaquinone is MK-7. Major polar lipids are diphosphatidylglycerol, phosphatidylglycerol and two unidentified phospholipids. The DNA G + C content of the type strain is $39.5 \mathrm{~mol} \%$ (determined by HPLC).

The type strain, IDS $-20^{\mathrm{T}}\left(=\right.$ KCTC $13727^{\mathrm{T}}=$ CCUG $\left.59308^{\mathrm{T}}\right)$, was isolated from a marine solar saltern on the west coast of Korea.

\section{Acknowledgements}

This work was supported by the Program for Collection, Management and Utilization of Biological Resources (grant M10867010003) and the 21C Frontier Program of Microbial Genomics and Applications (grant MG05-0401-2-0) from the Ministry of Education, Science and Technology (MEST) of the Republic of Korea.

\section{References}

Baumann, P. \& Baumann, L. (1981). The marine Gram-negative eubacteria: genera Photobacterium, Beneckea, Alteromonas, Pseudomonas and Alcaligenes. In The Prokaryotes, vol. 2, pp. 1302-1331. Edited by M. P. Starr, H. Stolp, H. G. Trüper, A. Balows \& H. G. Schlegel. Berlin: Springer.

Bruns, A., Rohde, M. \& Berthe-Corti, L. (2001). Muricauda ruestringensis gen. nov., sp. nov., a facultatively anaerobic, appendaged bacterium from German North Sea intertidal sediment. Int J Syst Evol Microbiol 51, 1997-2006.

Carrasco, I. J., Márquez, M. C. \& Ventosa, A. (2009). Virgibacillus salinus sp. nov., a moderately halophilic bacterium from sediment of a saline lake. Int J Syst Evol Microbiol 59, 3068-3073.

Chen, Y.-G., Cui, X.-L., Fritze, D., Chai, L.-H., Schumann, P., Wen, M.-L., Wang, Y.-X., Xu, L.-H. \& Jiang, C.-L. (2008). Virgibacillus kekensis sp. nov., a moderately halophilic bacterium isolated from a salt lake in China. Int J Syst Evol Microbiol 58, 647-653.

Chen, Y.-G., Cui, X.-L., Wang, Y.-X., Zhang, Y.-O., Tang, S.-K., Li, W.-J., Liu, Z.-X., Wen, M.-L. \& Peng, Q. (2009). Virgibacillus sediminis sp. nov., a moderately halophilic bacterium isolated from a salt lake in China. Int J Syst Evol Microbiol 59, 2058-2063.

Cohen-Bazire, G., Sistrom, W. R. \& Stanier, R. Y. (1957). Kinetic studies of pigment synthesis by nonsulfur purple bacteria. J Cell Comp Physiol 49, 25-68.

Cowan, S. T. \& Steel, K. J. (1965). Manual for the Identification of Medical Bacteria. London: Cambridge University Press.

Heyndrickx, M., Lebbe, L., Kersters, K., De Vos, P., Forsyth, G. \& Logan, N. A. (1998). Virgibacillus: a new genus to accommodate Bacillus pantothenticus (Proom and Knight 1950). Emended description of Virgibacillus pantothenticus. Int J Syst Bacteriol 48, 99-106.

Heyrman, J., Logan, N. A., Busse, H.-J., Balcaen, A., Lebbe, L., Rodriguez-Diaz, M., Swings, J. \& De Vos, P. (2003). Virgibacillus carmonensis sp. nov., Virgibacillus necropolis sp. nov. and Virgibacillus picturae sp. nov., three novel species isolated from deteriorated mural paintings, transfer of the species of the genus salibacillus to Virgibacillus, as Virgibacillus marismortui comb. nov. and Virgibacillus salexigens comb. nov., and emended description of the genus Virgibacillus. Int $J$ Syst Evol Microbiol 53, 501-511.
Hua, N.-P., Hamza-Chaffai, A., Vreeland, R. H., Isoda, H. \& Naganuma, T. (2008). Virgibacillus salarius sp. nov., a halophilic bacterium isolated from a Saharan salt lake. Int J Syst Evol Microbiol 58, 2409-2414.

Jeon, C. O., Kim, J. M., Park, D.-J., Xu, L.-H., Jiang, C.-L. \& Kim, C.-J. (2009). Virgibacillus xinjiangensis sp. nov., isolated from a Salt Lake of Xin-jiang Province in China. J Microbiol 47, 705-709.

Jeon, C. O., Kim, J. M., Park, D.-J., Xu, L.-H., Jiang, C.-L. \& Kim, C.-J. (2010). Virgibacillus xinjiangensis sp. nov. In List of New Names and New Combinations Previously Effectively, but not Validly, Published, Validation List no. 133. Int J Syst Evol Microbiol 60, 1009-1010.

Kämpfer, P., Arun, A. B., Busse, H.-J., Langer, S., Young, C.-C., Chen, W.-M., Syed, A. A. \& Rekha, P. D. (2011). Virgibacillus soli sp. nov., isolated from mountain soil. Int J Syst Evol Microbiol 61, 275-280.

Komagata, K. \& Suzuki, K. (1987). Lipid and cell wall analysis in bacterial systematics. Methods Microbiol 19, 161-207.

Lányí, B. (1987). Classical and rapid identification methods for medically important bacteria. Methods Microbiol 19, 1-67.

Leifson, E. (1963). Determination of carbohydrate metabolism of marine bacteria. J Bacteriol 85, 1183-1184.

Minnikin, D. E., O'Donnell, A. G., Goodfellow, M., Alderson, G., Athalye, M., Schaal, A. \& Parlett, J. H. (1984). An integrated procedure for the extraction of bacterial isoprenoid quinones and polar lipids. J Microbiol Methods 2, 233-241.

Niederberger, T. D., Steven, B., Charvet, S., Barbier, B. \& Whyte, L. G. (2009). Virgibacillus arcticus sp. nov., a moderately halophilic, endospore-forming bacterium from permafrost in the Canadian high Arctic. Int J Syst Evol Microbiol 59, 2219-2225.

Sasser, M. (1990). Identification of bacteria by gas chromatography of cellular fatty acids, MIDI Technical Note 101. Newark, DE: MIDI Inc.

Sehgal, S. N. \& Gibbons, N. E. (1960). Effect of some metal ions on the growth of Halobacterium cutirubrum. Can J Microbiol 6, 165-169.

Staley, J. T. (1968). Prosthecomicrobium and Ancalomicrobium: new prosthecate freshwater bacteria. J Bacteriol 95, 1921-1942.

Tamaoka, J. \& Komagata, K. (1984). Determination of DNA base composition by reverse-phase high-performance liquid chromatography. FEMS Microbiol Lett 25, 125-128.

Wang, C.-Y., Chang, C.-C., Ng, C. C., Chen, T.-W. \& Shyu, Y.-T. (2008). Virgibacillus chiguensis sp. nov., a novel halophilic bacterium isolated from Chigu, a previously commercial saltern located in southern Taiwan. Int J Syst Evol Microbiol 58, 341-345.

Wang, X., Xue, Y. \& Ma, Y. (2010). Virgibacillus subterraneus sp. nov., a moderately halophilic Gram-positive bacterium isolated from subsurface saline soil. Int J Syst Evol Microbiol 60, 2763-2767.

Yoon, J.-H., Kim, H., Kim, S.-B., Kim, H.-J., Kim, W. Y., Lee, S. T., Goodfellow, M. \& Park, Y.-H. (1996). Identification of Saccharomonospora strains by the use of genomic DNA fragments and rRNA gene probes. Int J Syst Bacteriol 46, 502-505.

Yoon, J.-H., Lee, S. T. \& Park, Y.-H. (1998). Inter- and intraspecific phylogenetic analysis of the genus Nocardioides and related taxa based on 16S rDNA sequences. Int J Syst Bacteriol 48, 187-194.

Yoon, J.-H., Kang, K. H. \& Park, Y.-H. (2003). Psychrobacter jeotgali sp. nov., isolated from jeotgal, a traditional Korean fermented seafood. Int J Syst Evol Microbiol 53, 449-454.

Yoon, J.-H., Oh, T.-K. \& Park, Y.-H. (2004). Transfer of Bacillus halodenitrificans Denariaz et al. 1989 to the genus Virgibacillus as Virgibacillus halodenitrificans comb. nov. Int J Syst Evol Microbiol 54, 2163-2167.

Yoon, J.-H., Kang, S.-J., Jung, Y.-T., Lee, K. C., Oh, H. W. \& Oh, T.-K. (2010). Virgibacillus byunsanensis sp. nov., isolated from a marine solar saltern. Int J Syst Evol Microbiol 60, 291-295. 